\title{
The alignment of product strategy to supply chain practices of craft businesses in Gauteng Province, South Africa
}

\author{
Authors: \\ Craig Voortman ${ }^{1}$ \\ K. Mercy Makhitha ${ }^{2}$ \\ Affiliations: \\ ${ }^{1}$ Department of Transport \\ and Supply Chain \\ Management, University of \\ Johannesburg, South Africa \\ ${ }^{2}$ Department of Logistics, \\ Vaal University of \\ Technology, South Africa \\ Correspondence to: \\ Craig Voortman \\ Email: \\ craigv@uj.ac.za
}

Postal address:

PO Box 524, Auckland Park

2006, South Africa

Dates:

Received: 28 Oct. 2013

Accepted: 18 June 2014

Published: 21 Nov. 2014

How to cite this article: Voortman, C. \& Makhitha, K.M., 2014, 'The alignment of product strategy to supply chain practices of craft businesses in Gauteng Province, South Africa', Journal of Transport and Supply Chain Management 8(1), Art. \#126, 11 pages. http://dx.doi.org/10.4102/ jtscm.v8i1.126

\section{Copyright:}

(C) 2014. The Authors. Licensee: AOSIS OpenJournals. This work is licensed under the Creative Commons Attribution License.
External factors such as blurring market boundaries, escalating customer diversity and increasing global competitive threats have forced businesses to build strategies around key products and formulate market-driven strategies that are integrated with relationship and supply chain strategies to deliver superior customer value. Indeed, in the modern era of supply chain management, organisations are getting more integrated with their suppliers and customers as a way to manage the total supply chain. The purpose of this research was to determine if product strategies and supply chain practices of small craft business are aligned. Personal in-depth interviews were conducted with nine craft businesses operating in Gauteng Province, South Africa. The findings revealed that craft businesses struggle to match their product strategies with their supply chain strategies. Craft businesses also exhibited some inbound supply chain weaknesses.

\section{Introduction}

The alignment of a business's product strategy with its supply chain strategy is a challenge for all businesses to master - whether they are small, medium or large enterprises. Whilst larger multinationals often have the skilled staff to make sure that their product strategy is closely aligned with their supply chain strategy, small-to-medium-sized enterprises often face significant challenges because they often do not have either the additional personnel or the skilfulness to do so. Small businesses often are 'time starved' because they typically have fewer staff members who must wear 'many hats' and must constantly multitask for the business just to survive - let alone thrive. However, small businesses are not just typically 'time starved', but often 'resource starved' as well. In other words, they are often pressured to perform many tasks in a short period of time in the working day with far fewer resources typically than the medium-to-large business. Typically, smaller businesses - especially 'start up' businesses - face significant resource challenges including human resource, financial resource, operational resource and asset resource challenges (in terms of vehicles needed, storage or warehousing space needed, as well as office space with required items such as sufficient computers and other capital asset requirements).

Small businesses often develop new or innovative products; yet, just making or sourcing these for the marketplace can be challenging given their abovementioned resource constraints, namely time, money, people and physical facilities. Many small businesses are often very successful with the early development and management of their product strategy whilst the products are new to the marketplace or selling in smaller volumes. Where they often struggle is with the more 'sophisticated art' of linking their product strategy to a more developed 'supply chain strategy' as their small business grows and an increasing number of products are sold. As sales volumes increase, more products are sold and these must be sourced or created. Problems often arise upstream in the supply chain (raw materials sourcing and related tasks), or even downstream in the supply chain once the product has been created (physical storage and distribution by road, rail, air or sea). There is little wonder then that such small businesses often struggle to align and fine-tune their product strategy with their supply chain strategy.

The alignment of these strategies within small craft businesses (in Gauteng Province, South Africa) is therefore the specific focus of this research. Whilst there has been scant research on craft supply chains in other parts of the globe, there has been no research conducted on the craft supply chains of smaller craft businesses operating within Gauteng, South Africa. Furthermore, very little information is available on how craft producers (who typically supply tourists and the tourism industry) align their innovative and inventive product strategies with similarly appropriate and successful supply chain management (SCM) strategies. In simple terms, one 
needs to identify whether they have sufficient vehicles to distribute the volumes of finished goods produced (outbound distribution), whether they have sufficient storage space to warehouse the products they produce and whether they match their inbound raw materials requirements with the volumes they produce (demand forecasting).

\section{Background}

\section{Management of multiple upstream and downstream linkages}

The integration of the supply chain, with closer linkages occurring between suppliers and customers is increasingly becoming a reality of modern supply chains and business enterprises. Companies nowadays have expanded their planning and control perspectives to include 'upstream' (suppliers) and 'downstream' (distributors and customers) entities. The integration of market-driven strategies with supply chain strategies has become a focus of many businesses in recent times as they strive to offer superior customer service (Burt, Petcavage \& Pinkerton 2012:119-121; Cravens, Piercy \& Prentice 2000:369; Trott 2012:412). Indeed, in the modern era of SCM, organisations are more 'integrated with their suppliers and customers in order to manage the total supply chain from raw materials to the ultimate customer, the only source of revenue' (Burt et al. 2012:459).

The challenge facing modern businesses - both large and small - is to constantly develop products and services that meet the ever-changing needs of customers (Arnold, Chapman \& Clive 2012:370). All businesses today face competitive challenges and one's product strategy - in terms of stock keeping units (SKUs) kept - impacts on cash flow and other business dimensions. Businesses constantly have to decide on the number and types of products to offer in the market (Hilletofth 2009:17), as well as how to manage these products more effectively in the presence of competitors and turbulent external environments. One of the key interfaces between marketing and logistics is deciding on the size and range of product offerings. The different perspectives of marketing and logistics becomes a cardinal concern when one has to decide how many SKUs to hold:

Marketers often prefer to carry higher quantities of particular items because this reduces the likelihood of stockouts (being out of stock at the same time as there is a demand for it). However, from a logistics perspective, higher quantities of inventory (1) necessitate additional storage space and (2) increase inventory carrying costs. (Murphy \& Wood 2011:32-33)

Therefore, the challenge facing all businesses is to make sure that they, (1) carry stock the market wants and needs, (2) in the right volumes and (3) that are sufficiently differentiated from competitors so as to give them a differentiating 'edge' in the marketplace.

\section{Product differentiation as a key focus of successful business strategy}

In the craft business, which is the focus of this article, product differentiation is a key positioning strategy because customers (often international or local tourists) must be convinced to purchase 'your' particular and unique product that is offered:

Many basic differences exist between the kinds of products marketed in the various segments of the economy. Some products in the competitive segment are undifferentiated (not distinguished by specific differences), whilst other products are differentiated. In some cases the products are intrinsically different (differentiated); in others, manufacturers are successful at making their products appear different from those of their competitors. Even in those cases where a product cannot be made different in substance, producers can get premium prices if they persuade customers to believe that their products are superior. (Burt et al. 2012:459)

In layman's terms, three 'categories' of product differentiation would apply to the craft industry. Firstly, the products that are actually different from other crafts available in craft shops or tourist 'flea markets'. Secondly, some suppliers or manufacturers can make some products appear different from their competitors when very few differences are actually present. Thirdly, some suppliers or sellers of crafts can simply make their customers believe that their products are different from other competitors, when in fact they are virtually identical. The power of persuasive marketers or salespeople would obviously be paramount in the third example because one would have to influence the perception of the customer in such a way that they would indeed think or believe that one's product was actually different (when in fact it was not!).

As businesses (including craft businesses) offer a wide variety of products, appropriate SCM strategies must be put in place and integrated with product strategy in order to create competitive advantages. This is because one single supply chain strategy cannot be applicable to the different types of products and markets that a business sources (Hilletofth 2009:16). In order to offer a wide variety of products to the craft industry, one's product or service strategy must be fully integrated with the supply chain. A fully integrated and well-coordinated supply chain will result in craft supplies being created and produced on time for demand (lead time management), created according to the unique and everchanging needs of a diverse customer set, as well as being produced in a cost-efficient and profitable manner for the ultimate seller of the crafts. Hugo and Badenhorst-Weiss (2013:18) underscore the essential need for demand-driven sales planning, lean manufacturing and the integration of processes which will result in reduced cycle times for both large and small businesses.

\section{Structuring the supply chain for product differentiation, product range, profitability and customer satisfaction}

The craft supply chain - as is the case with any successful supply chain - needs to be structured such that it supports a successful business unit, a particular product range or a specific item that is sold (Pienaar \& Vogt 2012:36-41; Quayle 2003:79). The design of supply chain activities depends on the product strategies being adopted. If one is going for mass-produced products, then very little product differentiation takes place as all products manufactured should be identical. However, in the craft industry, product 
differentiation is of paramount importance and will influence whether the final customer either purchases one's product or not.

The ability of the supply chain to offer a uniquely differentiated craft product places additional pressure on the producers of such products and they must constantly explore new and unique (different) ways of manufacturing crafts that customers will like and buy. It has been observed by the researchers that when a craft maker produces something unique and different for the tourist craft market, it is simply a matter of time before a number of 'copied' imitations appear in the craft market. The early innovation is quickly followed by replicators - and the replications then quickly become mass produced - until such time as the tourist no longer purchases these replications. The innovation cycle then begins again with a new innovation which is offered to the tourist market and shows early success, only to be imitated once again by fellow competitors. Product differentiation strategies thus form the basis for supply chain development and should be determined based on the understanding of customer requirements, competitor offerings and unique product offerings (Quayle 2006:7; Trott 2012:25, 210-211).

\section{Current supply chain management and product strategy research often favours larger businesses}

Research on SCM and product strategy has principally focused on large (multinational) businesses (Burt et al. 2012:479). The impact of SCM on the product strategy of small businesses has not been extensively researched (Merrilees 2007:403). This is particularly the case with small craft businesses where product design and development are regarded as two separate functions that cannot be integrated (Lambert \& Cooper 2000:72).

Craft businesses often design and produce unique products first and foremost and then decide on the markets and customers as an afterthought. Most modern multinational large businesses would seldom, if ever, do this. Rather they will first conduct thorough market research through lengthy questionnaires, focus-group analysis and product sampling and testing, before even considering launching the new product offering in the marketplace. As there are often vast sums of money (research and development funds) invested in such product roll-out strategies, they minimise their risk of market success by carefully, and meticulously, first testing the customer's response to their proposed product prior to launching it in the intended market (through targetmarketing as well as random sampling and testing and a host of other market research techniques).

The methodology of new product design and development strategies of small craft businesses is significantly different to large, sophisticated enterprises with extensive capital at their disposal to do extensive pre-launch testing and related product development. Not only do small craft businesses often consider their customer market after their product has been created and even manufactured, but they also only often factor in how the product will be sourced and supplied (or manufactured) in the post-design phase of the product's life cycle. The supply chain activities of small craft businesses are therefore often more reactive rather than proactive. Small businesses, according to Vaaland and Heide (2007:21), often do not employ SCM effectively and small craft businesses are no different in this respect. As a result, small craft businesses often face various logistical and supply chain challenges such as excessive inventory, poor customer service, declining profits and escalating costs.

Effective lead time management is well-acknowledged with large enterprises but is also critically important in small craft businesses. As consumers demand lower prices and higher quality products and services, retailers, manufacturers and distributors are under pressure to achieve greater costefficiencies and improve lead times, which makes supply chain efficiency a key factor in gaining a competitive advantage (Arnold et al. 2012:71; Burt et al. 2012:79; Mangan et al. 2012:206; Quayle 2003:79). The benefits of an integrated supply chain are that it leads to reduced inventory costs, higher quality products and higher customer service levels (Burt et al. 2012:79; Pienaar \& Vogt 2012:8; also Hugo \& Badenhorst-Weiss 2013:121 on quality and overall value analysis for the customer). Understanding and identifying appropriate supply chain techniques requires one, firstly, to know which products will sell most frequently and, secondly, which market segments exist (Pienaar \& Vogt 2012:41-42), because clearly defined product strategies are key to the establishment of an effective supply chain (Quayle 2003:79).

\section{The purpose of the article}

Research on the impact of supply chain design on product strategy for small businesses is sparse. The supply chain includes upstream linkages (from the raw materials and manufacturing side), internal linkages (either manufacturing or crafting, or internal business processes) and downstream linkages (focused on the end customer); this research will focus primarily on the internal and downstream linkages. Internal linkages include those value-creating activities that relate to the process of transforming raw materials into finished products and services (Naudè \& O'Neill 2009:10), whilst downstream linkages refer to distribution activities involved in warehousing, storing, order processing, order picking and packing, shipping, delivery vehicle operations and distributing the finished product to the customer (Hough et al. 2008:121). Marketing, distribution and customer sales and satisfaction are the downstream activities, whilst the upstream portion of the organisation's value chain focuses on feeding the production or conversion process of the supply chain (Burt et al. 2012:10).

In light of the above, the purpose of this article is therefore to determine if product strategies are aligned to supply chain practices in craft businesses in Gauteng, South Africa. This research will also show that significant challenges are often faced by small-to-medium-sized craft businesses (in 
Gauteng) in aligning their product strategies with their supply chain strategies. One may also logically be able to extrapolate that if small-to-medium-sized craft businesses face alignment problems, then other similar small-tomedium-sized businesses in other industries may also face similar challenges to those of craft businesses. In other words, if small-to-medium-sized craft businesses face significant challenges in matching or aligning the gap between their product and supply chain strategies, then other similar-sized businesses will face similar challenges both in South Africa and other parts of the world. However, this latter statement will not be proven or discussed in this research article as it is beyond the scope of this research project (research limitation).

\section{Literature review \\ Defining supply chain management}

Scholars on SCM have conceptualised the supply chain in similar, yet slightly differing ways. However, most definitions emphasise the importance of integrating supply chain activities that need to be managed, coordinated and integrated in a cost-effective manner to ensure the satisfaction of all concerned. The Global Supply Chain Forum define the supply chain as the integration of key business processes from end user through to original suppliers, and which provides products, services and information that add value for customers and other stakeholders (Lambert \& Cooper 2000:66). It includes upstream linkages, such as sources of supply, the internal linkages inside the organisation and downstream linkages such as distribution to ultimate customers. These activities are concerned with the integration of business processes from end user through to original suppliers that provide products, services and information and add value for customers (Burt et al. 2012:119-121; Cant et al. 2006:45; Hugo \& Badenhorst-Weiss 2013:17-18; Mangan et al. 2012:171-172; Trott 2012:412).

Supply chain management is also defined as a set of approaches utilised to efficiently integrate and coordinate the materials, information and financial flow across the supply chain so that merchandise is supplied, produced and distributed at the right quantities, to the right location, at the right time, in the most cost efficient way, whilst satisfying customer requirements (Hilletofth 2009:16).

The concept of SCM has four major components that must be managed:

- The flow of physical materials from suppliers, downstream through the business itself and finally to distributors and/or customers.

- The flow of money upstream from customers back to companies and suppliers.

- The flow of information up and down the stream.

- The flow of products back (upstream) from the customers, typically for repair or recycling (Arnold et al. 2012:162).

Supply chain management has thus evolved to become a much more sophisticated science with multiple upstream and downstream linkages that need to be carefully managed:
Supply chain management ... is the management, across and within a network of upstream and downstream organisations, of both relationships and flows of materials, information and resources. The purpose of supply chain management is to create value, enhance efficiency, and to satisfy customers. (Mangan $e t$ al. 2012:11; also Pienaar \& Vogt 2012:145)

In addition, SCM has also become an important tool for businesses to achieve competitive advantages (Cooper \& Ellram 1993:14; De Villiers, Nieman \& Niemann 2012:11; Hugo \& Badenhorst-Weiss 2013:17; Lummus \& Vokurka 1999:15; Vaaland \& Heide 2007:20).

Sutherland and Canwell (in Pienaar \& Vogt 2012:8) define the supply chain as the integrated management and control of the flow of information, materials and services from suppliers of raw materials, through to the factories, warehouses and retailers, to the end customers. It includes all the activities that are involved in delivering products from the raw material phase to the customer, including the sourcing of raw materials and parts, production and assembly, warehousing and inventory assembly, order planning and order management, distribution across all channels and delivery to the customer (Lummus, Krumwiede \& Vokurka 2001:429; Tan 2001:40). The primary purpose is efficient physical distribution of final products from manufacturers to end users in an attempt to replace inventories based on useful, up to date information (Arnold et al. 2012:120-121; Tan 2001:40).

\section{Conversion of raw materials into finished products}

The purpose of SCM is to support the transformation of raw materials and component parts into shipped or inventory goods, a cardinal activity for all craft businesses (Arnold et al. 2012:197; Benton 2007:5; Hugo \& Badenhorst-Weiss 2013:178; Pienaar \& Vogt 2012:57-59). Its main function is to provide goods and services as required by customer and also to provide form, time, place and quantity utilities (Quayle 2006:7). Integrating all supply chain activities may create competitive advantages for the organisation if such activities are run efficiently and effectively (Pienaar \& Vogt 2012:482). This is because the decision by one supply chain member affects the activities of other supply chain members (Benton 2007:9; Pienaar \& Vogt 2012:19-21).

\section{Cost-efficient supply chains require a reduction in inbound costs}

The increasing demand for a cost-effective supply chain has put pressure on all businesses to cut costs (Mangan et al. 2012:190). Therefore, a cost-effective supply chain is a means of survival for businesses as purchased goods and services account for $80 \%$ of sales revenue (Quayle 2003:79). Supply chain management serves to manage activities required for specific products, such that there is a significant competitive advantage in the production of quality products that are cost-effective (Benton 2007:7). Thus, SCM is important for three reasons: to reduce inventory management, to increase customer service and to help build competitive advantages (Cooper \& Ellram 1993:14). Well-managed supply chains help create competitive advantages and lead to increased profit for the business through coordinated attention to 
costs, customer service, reduced inventory levels and reduced inventory carrying costs (Cooper \& Ellram 1993:14; Hugo \& Badenhorst-Weiss 2013:9; Pienaar \& Vogt 2012:225227). Small businesses are less likely to employ a person to facilitate supply chain management as their operations are less sophisticated, which could lead to an increase in costs and, typically, to an unacceptable level of customer service (Murphy, Daley \& Knemeyer 1999:18).

\section{The product strategies used by small businesses for gaining competitive advantages}

Product strategy is concerned with the position of the product in the market, attributes and characteristics, its life cycle, buyer behaviour, price, promotion, distribution, customer service and packaging requirements (Gould 2012:65; Rainey 2005:360; Trott 2012:67). Decisions on product strategy are made at various levels - corporate, business and operational. Product strategy includes decisions on product assortment or mix, business unit decisions, product line, number of product per product mix or group, choice of target market, desired positioning and product attributes such as brand elements, product development and improvement, packaging and service level (Alsem 2007:25).

With large businesses, marketing managers are responsible for making marketing and product strategy decisions (Morgan, Daniels \& Kouvelis 2001:949). With small businesses, ownermanagers are responsible for various tasks including product development and management, product portfolio (range) management, marketing, production and purchasing, human resources and so forth (Arbuthnot, Slama \& Sisler 1993:13). Smaller businesses have no choice but to centralise these functions and have limited specialisation because of fewer personnel available to specialise in certain functions (Hong \& Jeong 2006:295). These managers of smaller businesses often lack the time, skills and expertise required to manage their product portfolios successfully and effectively (Tang, Wang \& Zhang 2007:19). They become generalists instead of specialists because they perform all functions and therefore may not be able to specialise in all these areas (Gilmore, Carson \& Grant 2001).

\section{Product brand strategies and development of brand equity}

Product strategy decisions also relate to decisions about brand equity, which establishes a link between a business and the new products offered because a business reaps the benefits of owning such a product brand (Rainey 2005:363). Brand equity is the term used to describe the value of a brand name and creates value for both customers and the firm (Shimp \& Andrews 2013:31). For example:

The brand can give customers confidence in the purchasing situation. Firms benefit enormously from having strong brand names. Investment in a brand name can be leveraged through brand extensions and increased distribution. High brand equity often allows higher prices to be charged; hence it is a significant competitive advantage. (Trott 2012:177)

Brand equity is thus very important and the research conducted amongst the craft businesses consulted revealed that not all of the craft businesses understood the value of brand equity and a brand name, nor did they actively utilise or develop brand equity.

Product brand strategies also look at how a product will be positioned in the market against competitors (Cravens \& Piercy 2009:199; Trott 2012:389-392). As part of corporate strategy, businesses make decisions on the range and assortments of products to produce and market (Brander \& Eaton 1984:327; Pelligrini \& Zanderighi 2001:157). A product assortment is a set of all product lines and individual products that a firm sells (Perreault \& McCarthy 1996:279). It involves the selection of a range of components and the management of the product range by adding or removing of individual products within a range (Davies 1994:475). Businesses also have to eliminate products that do not merit marginal evaluation or that are low sellers in order to make their procurement function and overall business strategy more efficient (McLaughlin \& Rao 1990:359).

\section{Effective product differentiation and diversification strategies}

Businesses that differentiate their products from those of competitors create a competitive advantage over their competitors. A competitive advantage is the ability to deliver superior value to the market over a protracted period of time (Cant et al. 2006:197; Hugo \& Badenhorst-Weiss 2013:19). A business achieves a sustainable competitive advantage when an attractive number of buyers prefer its products and services over those of competitors (Hough et al. 2008:5). Product assortment involves making decisions on the family, classes and lines of product to stock, product types per line, brands per type, items per brand within a product type, as well as the allocation of shelf space to each item (Pelligrini \& Zanderighi 2001:157). Some businesses also add different sizes, styles, colours, flavours or products as a way of extending their product lines and thereby differentiating themselves even further from their competitors (McLaughlin \& Rao 1990:359).

Certain marketing specialists believe that product variety offers a business market power, which, in turn, increases the profit margin and market share; this has therefore led many businesses expanding their product lines (Hopp \& $\mathrm{Xu}$ 2005:172). Expanding product lines is known as product diversification, which simply means the expansion of the product mix by adding new product ranges or items (Cravens \& Piercy 2009:98). It may also result into expanding to new markets and the introduction of new products (Cant et al. 2006:212). Ideally businesses - both large and small - try to develop products and services that are difficult to copy (Gould 2012:70), which often results in a sustainable competitive advantage:

Sustainable competitive advantages provide the organisation with more time to exploit them in winning and keeping customers and in growing the business. These advantages represent the crown jewels of any organisation, providing the opportunity to create real competitive differentiation in the marketplace. (Gould 2012:70) 
Creating a real competitive differentiation in the marketplace is one of the obvious goals of the craft industry - each and every craft producer, supplier and seller tries to offer the market a product that is unique and/or difficult to copy.

Product diversification may lead to increased costs because new and different products with different features have to be produced. These products might require different equipment, expertise, machinery requirements, as well as a different supply chain, which may ultimately lead to increased costs. Although expanded product lines offer a business the opportunity to differentiate themselves, it also increases the level of complexity and increased costs of product fulfilment (Hopp \& Xu 2005:172).

Although some small businesses do not want to grow, they all need to adapt to the changing environment and customer needs, even if they do desire to stay small businesses (Hogarth-Scott, Watson \& Wilson 1996:6). For small businesses to grow, they need to recognise and exploit market opportunities through the use of advanced manufacturing systems, creating new distribution channels, products and services and customer segments. Small businesses often serve market niches and have narrow specialisation (Hong \& Jeong 2006:294). They are known to introduce new products without prior research, which increases product failure as these new products have not been pre-screened or 'tweaked' based on focus-group feedback and surveys. They do not have well-defined strategies in place to manage the product mix or the new product development process (Trott 2012:383). Although they are known to exploit market niches, some introduce new products and product lines in the hope of growing and sustaining their businesses (Salavou \& Avlonitis 2008:971). However, small businesses need to determine the right product variety to meet the needs of the market (Jiao \& Zhang 2005:802).

Small businesses have, in general, limited ability to compete because of a number of constraints such as the lack of access to technology, excessive costs of product development, ineffective selling techniques and market research, information gaps between marketing and production functions and excessive capital requirements (Simpson \& Taylor 2002:370). Most small businesses enter the market led by a single product or technology, without the significant finance required for broadening their product range (Laforet \& Tann 2006:363).

The various classifications of innovation indicate that innovation can take place with new products (radical) or by making improvements to existing products (incremental). Incremental innovation happens when a business gradually improves its products, services and processes in response to customer needs, whilst radical innovation leads to the development of entirely different and new products, new processes and new markets (Trott 2012:15-18, 25, 210-211).

O'Dwyer and Ledwith (2009:132) reveal that businesses which are good in bringing new products to the marketplace perform better and that those which are good at launching new products are likely to have those new products succeed. They often have advantages over big businesses in the sense that they are close to customers, work within an informal and flexible environment, have a risk-taking attitude and can quickly change and adapt to a new way of doing things - something which bigger businesses often find very difficult to do (although there are noteworthy exceptions such as the Apple Company with their innovative iPhone, iPad and iPod which were all radically different from other competitors' offerings when they first launched). The ability of small businesses to introduce new products in the market also creates opportunities in new niche markets, which is important for business survival (Laforet \& Tann 2006:366).

Small businesses with long-term strategies were found to create and exploit new market niches with innovative products very effectively; furthermore, they were found to outperform those businesses who only changed their products gradually over a longer period of time (Mosey et al. 2002:176, 183; Salavou \& Avlonitis 2008:971). Big businesses are often content to survive in their original markets and often simply turn to existing products and markets, regardless of changes in the market and the external environments. Certain businesses survive and thrive through the releasing of new innovative products into the market whilst many large businesses simply maintain the status quo and offer few (if any) radical new product offerings (Mosey et al. 2002:176).

\section{Integrating product strategy and supply chain management for competitive advantages}

An integrated supply chain requires continuous information flows which lead to best product flows (Ghiani, Laporte \& Musmanno 2013:5-6; Lambert \& Cooper 2000:72; Mangan et al. 2012:114-116; Pienaar \& Vogt 2012:57, 71). Supply chains are effectively designed during the product development stage, when product, process and information system decisions are specified and determined. Decisions, such as functionality of the product, packaging, logistical channels, source of materials, as well as selection of product and process technology, are also made during the supply chain design stage (Petersen, Handfield \& Ragartz 2005:372). New product design can often change one's design of the whole supply chain; new product designs can therefore often result in substantial changes to one's existing supply chain setup and process (from suppliers through production to final consumers).

Product strategy also includes the physical characteristics of the product, which, in turn, influences supply chain costs, such as storage, handling and transportation (Ghiani et al. 2013:123, 210-213, 318-319). As a result, an integrated supply chain will be more cost-effective for the business (Hugo \& Badenhorst-Weiss 2013:78). This requires that one's product strategy must take into account supply chain requirements such as transport and storage, which leads to improvements in profits, or, if poorly executed, extra costs (Khan \& Creazza 2009:305). Integrating and involving SCM early in the product design and development stages helps minimise 
overall supply chain costs whilst improving customer service levels and logistics performance (Mather 1992). Supply chain management can be useful in differentiating a business from its competitors, and can also help create a marketing opportunity for a product that is supported by an effective and efficient supply chain (Lummus \& Vokurka 1999:16).

Research by Khan and Creazza (2009:317) reveals the lack of integration in the supply chains of small businesses, especially the downstream linkages in the supply chain, through distributors and on towards retailers. Khan and Creazza (2009:317) further suggest the establishment of cross-functional teams for the development of new products, teams which involve all relevant resources to be included in the design process so as to enable small businesses to restructure their supply chain and to integrate it with product strategy. Lack of integration downstream can generate misalignments with the market, causing delays to the effective launch of new products - which could ultimately lead to new product failure (Khan \& Creazza 2009:313). The integration of internal processes with external stakeholders such as suppliers and customers are essential for effective SCM to occur (Lummus \& Vokurka 1999:15). Linking one's supply chain strategy to a business strategy requires one to carefully define the business and supply chain processes involved in producing a product or service (Lummus \& Vokurka 1999:16). This might be a problem for some small businesses, such as those involved in craft production, where the owner manages the business, produces and market the products. Craft businesses are typically owner-managed and usually run by owner-managers with few (if any) employees. Certain businesses interviewed did however employ one or two employees within their businesses.

\section{Research method and design}

A qualitative case study research method was adopted for the study. This research method is similar to that adopted by Khan and Creazza (2009) to explore the interface between product design and the supply chain. A qualitative research method was deemed appropriate as it is concerned with the participant's spoken word, pertaining to their experience or perception (Brynard \& Hanekon 2006:37). Data were collected by means of face-to-face interviews with the respondents. Interviews lasted between one and a half to two hours. Respondents were visited at their business premises, which made it possible for the researcher to see their products and production points. As they did not have to take time off work, respondents were cooperative. Nine small, craft production businesses were targeted. This is similar to other studies conducted by Hogarth-Scott et al. (1996:618) who interviewed 18 businesses and Mosey (2005) who interviewed five businesses. Qualitative study allows one to explore the topic at hand and is appropriate when there is lack of data on the topic, as is the case with the craft industry.

The study targeted different craft businesses within the industry, including ceramics, homeware, décor, beadwork, fashion, jewellery, recycled materials and clay. A convenience sampling methodology was adopted for the study because there is still no accessible and established database of craft businesses in South Africa. Municipalities in Gauteng have been in the process of creating such a database but this has yet to be finalised. Respondents were selected from the Gauteng Economic Development Agency database of crafters that were selected to take part in their exhibition which was hosted in Gauteng. Only those operating in the Johannesburg area were targeted because of time constraints relating to travel and associated costs that would have arisen should interviews have been conducted in Cape Town, Durban, Port Elizabeth or other areas. Field notes were taken during the interviews with nine owner-managers and it was ensured that respondents provided information on each of the elements of a marketing strategy. This was achieved by transcribing from field notes which were typed into a Word document. As the questionnaire was designed to cover various sub-topics under investigation, data were analysed for each of the stated topics using content analysis.

\section{Results}

\section{Demographic profile}

The business profile of respondents is shown in Table 1 . Respondents have been in operation for more than 4 years, with 3 of them having operated for a longer period: Respondent 3 for 8 years, Respondent 6 for 10 years, and Respondent 9 for more than 13 years. Except for Respondent 7's business, which operates as a partnership, all the other businesses are individually owned. Respondents run different craft businesses such as jewellery, ceramic, interior and office décor and fashion. Businesses are owner-manager run,

TABLE 1: Business profile of the businesses interviewed.

\begin{tabular}{|c|c|c|c|c|c|c|}
\hline Type of craft business & Business ownership & $\begin{array}{l}\text { Number years } \\
\text { in business }\end{array}$ & Number of employees & Annual revenue & $\begin{array}{l}\text { Business registered: } \\
\text { Yes or no }\end{array}$ & $\begin{array}{l}\text { Gender: } \\
\text { Male or female }\end{array}$ \\
\hline Respondent 1: jewellery & Individually owned & 6 & 1 (employ temporary staff when needed) & R100 000 & Yes & Male \\
\hline Respondent 2: ceramic & Individually owned & 5 & 3 (employ temporary staff when needed) & R200 000 & Yes & Male \\
\hline $\begin{array}{l}\text { Respondent 3: interior } \\
\text { décor, office }\end{array}$ & Individually owned & 8 & $\begin{array}{l}4 \text { employed, but each are trained to start } \\
\text { their own business }\end{array}$ & No record & Yes & Female \\
\hline Respondent 4: interior décor & Individually owned & 5 & 1 (employ temporary staff when needed) & R40 000 & Yes & Female \\
\hline Respondent 5: ceramic & Individually owned & 6 & 1 (employ temporary staff when needed) & R300 000 & Yes & Male \\
\hline Respondent 6: ceramic & Individually owned & 10 & 1 (employ temporary staff when needed) & R80 000 & Yes & Male \\
\hline Respondent 7: fashion & Partnership & 4 & 2 (employ temporary staff when needed) & R500 000 & Yes & Male and Female \\
\hline Respondent 8: interior décor & Individually owned & 4 & 1 (employ temporary staff when needed) & R100 000 & Yes & Male \\
\hline $\begin{array}{l}\text { Respondent 9: fashion } \\
\text { and frames }\end{array}$ & Individually owned & 13 & 1 (employ temporary staff when needed) & R60 000 & Yes & Female \\
\hline
\end{tabular}


with the exception of Respondents 3 and 7: Respondent 3 employs additional people who help with the design and manufacturing of products, whilst Respondent 7 works with a business partner. All the respondents employ additional people when demand is high. All the businesses are formal and registered businesses. They are male-run businesses, except for Respondents 3, 4 and 9 which are female-run businesses. Respondents' revenues vary from R40 000 to R500 000 per year, except for Respondent 3 who has no record of annual revenue. Although some businesses have been operating longer than others, these have not necessarily been performing better than the more recently established craft businesses. For example, Respondent 9 has been in operation for 13 years, yet their sales revenue is lower than for Respondent 7 who has been operating for just 4 years. Respondent 3 pays no rental because she operates from her house. She works with three other people, but they sometimes operate without income as the businesses does not generate sales on a monthly basis.

\section{Number of product lines sold}

Except for Respondent 3, who has six product lines, respondents have between two and five product lines. As small businesses are owner-managed, it makes sense that these businesses have narrow product lines because they might not be able to manage all the product lines effectively. As shown in Table 2, Respondents 1, 3, 4, 5, 6, 8 and 9 also have a narrow product assortment, whilst Respondents 2 and 7 have a deeper one. Respondents 1, 3, 4, 6, 8 and 9 also do not have brand names for their products, whereas
Respondents 2, 5 and 7 do have branded products. For example, one respondent has two brand names, one for the local market and the other for international market.

\section{Product differentiation and associated supply chain cost implications}

Respondents 1, 3, 8 and 9 standardise their products across market segments. They do, however, differentiate their product designs from those of competitors. Only Respondent 4 makes and sells products that are similar to those of competitors. Products are made for different customer groups, including trade customers, tourists, local consumers and the export market. Respondent 3 produces products similar to those of any other producer supplying office stationery and interior décor, but most significantly differentiates her products through the type of raw materials that she uses, such as the use of sand and recycled materials (which results in innovative fresh product designs which are popular). With regards to sand as a raw material, she has gained a competitive advantage through lowering her cost of raw materials as the sand used is easily obtainable and obviously very inexpensive to source. She can therefore charge lower prices than her competitors by simply substituting one inbound sourced material over another more expensive one. She also has an advantage through the uniqueness of raw material (sand), which makes her stand out from her competitors.

Whilst a number of craft businesses do produce products that are difficult to copy, there were also certain craft businesses that proactively and innovatively used recycled materials to

TABLE 2: Product strategies used by the craft business respondents.

\begin{tabular}{|c|c|c|c|c|c|c|}
\hline $\begin{array}{l}\text { Respondent } \\
\text { number }\end{array}$ & Type of products & $\begin{array}{l}\text { Number } \\
\text { of product } \\
\text { line(s) }\end{array}$ & Product assortment & $\begin{array}{l}\text { Brand name and } \\
\text { logo }\end{array}$ & Designs & $\begin{array}{l}\text { Standard versus customised } \\
\text { products }\end{array}$ \\
\hline 1 & $\begin{array}{l}\text { Jewellery, telephone wire and glass } \\
\text { beads, platters for interior use }\end{array}$ & 2 & $\begin{array}{l}\text { Narrow - } \\
1 \text { design, but different colours }\end{array}$ & No & $\begin{array}{l}\text { Owner registered his } \\
\text { own designs }\end{array}$ & $\begin{array}{l}\text { Similar designs for all types of } \\
\text { customers }\end{array}$ \\
\hline 2 & $\begin{array}{l}\text { Ceramic ware vases, platters, and plant } \\
\text { pots; other products: candle holders, } \\
\text { art frames, cutlery }\end{array}$ & 5 & $\begin{array}{l}\text { Deep - } \\
\text { different colours and designs }\end{array}$ & $\begin{array}{l}\text { Stamps business } \\
\text { name and contact } \\
\text { details on the } \\
\text { products }\end{array}$ & $\begin{array}{l}\text { Own, also copies } \\
\text { from other } \\
\text { established } \\
\text { businesses }\end{array}$ & $\begin{array}{l}\text { Customises for customers - size, } \\
\text { colours, but uses similar designs }\end{array}$ \\
\hline 3 & $\begin{array}{l}\text { Interior décor using recycled paper and } \\
\text { sand }\end{array}$ & 6 & $\begin{array}{l}\text { Narrow }-1 \text { or } 2 \text { designs per } \\
\text { product lines, needs to update } \\
\text { of designs and product lines }\end{array}$ & No & $\begin{array}{l}\text { Similar design to } \\
\text { existing products } \\
\text { except for use of } \\
\text { sand as raw material }\end{array}$ & $\begin{array}{l}\text { Standard } \\
\text { designs for all types of customers } \\
\text { - copied from competitors }\end{array}$ \\
\hline 4 & $\begin{array}{l}\text { Beaded dolls, beaded fridge magnet, } \\
\text { jewellery, baskets }\end{array}$ & 4 & Narrow - similar to competitors & No & $\begin{array}{l}\text { Copied, similar to } \\
\text { many other designs } \\
\text { in Gauteng }\end{array}$ & $\begin{array}{l}\text { Similar designs for all types of } \\
\text { customers }\end{array}$ \\
\hline 5 & $\begin{array}{l}\text { Ceramic ware - } \\
\text { cups, plates, teapots, floor tiles, trays, } \\
\text { toilet roll holders }\end{array}$ & 3 & $\begin{array}{l}2 \text { different designs - plain and } \\
\text { African 'Big Five' animals theme }\end{array}$ & $\begin{array}{l}\text { Stamps business } \\
\text { name and contact } \\
\text { details on the } \\
\text { products }\end{array}$ & Own, unique & $\begin{array}{l}2 \text { designs - one for local and } \\
\text { other for international market; } \\
\text { products can be personalised } \\
\text { with customer names; unique } \\
\text { selling advantage of personalised, } \\
\text { customised products }\end{array}$ \\
\hline 6 & $\begin{array}{l}\text { Ceramic ware - } \\
\text { pots, cups and plates }\end{array}$ & 3 & $\begin{array}{l}\text { Narrow - one shape, one colour, } \\
\text { three sizes }\end{array}$ & No & Own, unique & Customised for trade customers \\
\hline 7 & Fashion designers & 4 & $\begin{array}{l}\text { Deep - many different designs } \\
\text { for different markets }\end{array}$ & $\begin{array}{l}4-\text { brand names } \\
\text { for each product } \\
\text { line }\end{array}$ & Own, unique & Customised products \\
\hline 8 & $\begin{array}{l}\text { Picture frames, wall clocks, artificial } \\
\text { flowers and pots }\end{array}$ & 4 & $\begin{array}{l}\text { Narrow - only } 1 \text { design per } \\
\text { product line but different colours }\end{array}$ & No & Own, unique & $\begin{array}{l}\text { Similar designs for all types of } \\
\text { customers }\end{array}$ \\
\hline 9 & Paintings and fashion design & 3 & $\begin{array}{l}\text { Narrow - but different colours } \\
\text { used }\end{array}$ & No & Own, some copied & $\begin{array}{l}\text { Standardised for all types of } \\
\text { customers, except for paintings } \\
\text { that can be customised }\end{array}$ \\
\hline
\end{tabular}


produce very good quality products. The literature review confirms that there is indeed a business case for utilising green opportunities in the supply chain setting. Hugo and Badenhorst-Weiss (2013:96) underscore the possible business opportunities in their discussion entitled 'Greening opportunities throughout the supply chain'; similarly, Iannuzzi (2012:76-77) also has a pertinent discussion on 'green and healthy product design factors' and how waste can be effectively used to make money in innovatively designed products.

\section{Use of brand names and unique design features in the product design process}

Respondent 7 has four brand names, each used specifically for different market segments. He makes fashion products, traditional clothes, contemporary clothes, as well as wedding and classical lines for men and women. He has different designs, including innovative cultural design (African designs with tribal or cultural styles clearly evident), as well as modern and contemporary ones, and still manages to customise designs for different customers. His product assortments vary in terms of colours used, designs, and sizes and, in addition, he can adapt the product to customer's specifications. Burt et al. (2012:136) feature an in-depth discussion on the 'Categories of specifications' and certain of these specification categories are evident in the product design process of this crafter.

Respondents 5 and 6 both stamp their products with their business name and contact details. This is important for repeat buying as a customer can phone to place an order or refer other customers to this respondent. Respondent 6 can also adapt his designs to meet specific needs of customers and customise products for customers. Products come either in plain colours or in African 'Big Five' animal designs and he has two different designs: one for the local market and one for export. Respondent 2 customises his products through the use of different colours and sizes based on customer's request.

Respondent 4 creates unique designs. He produces interior décor products such as cases and kitchenware. He has a narrow product assortment: he creates one design for each product, using the same colour with three different sizes. Although this helps to distinguish him from competitors, it also limits his business growth as some of the customer's demand that he sell to them and not their competitors. With such a narrow assortment and with exclusive contracts to supply one customer, he might need to increase his product assortment by adding different colours, which would free him up from any 'exclusive' agreements and he would obviously then be able to sell more and make more money.

Retailing and distribution strategies differ from respondent to respondent (see Table 3). With regard to the availability of products, customers can visit all of the Respondent's factories or stalls where they can buy and collect the products. In terms of general transportation to customers, products can also be delivered to customers, as is the case with Respondents 1 , $2,5,6,7,8$ and 9 . In terms of outbound transportation of finished goods, respondents can either deliver personally to customers or courier the products anywhere in the world.

TABLE 3: Dimensions of the supply chain used by the craft business respondents.

\begin{tabular}{|c|c|c|c|c|c|}
\hline $\begin{array}{l}\text { Respondent } \\
\text { number }\end{array}$ & Distribution method used & $\begin{array}{l}\text { Order placement } \\
\text { and lead time }\end{array}$ & $\begin{array}{l}\text { Transportation } \\
\text { method for product delivery }\end{array}$ & Factory, storage and warehousing & $\begin{array}{l}\text { Internet access and } \\
\text { own computer }\end{array}$ \\
\hline 1 & $\begin{array}{l}\text { Customers visit the factory and } \\
\text { purchase at the factory; deliver } \\
\text { to customers, both locally and } \\
\text { internationally; trade and tourism } \\
\text { exhibitions used }\end{array}$ & $\begin{array}{l}\text { Factory visit, by phone or via } \\
\text { email, or at exhibitions; big } \\
\text { order - } 2 \text { week lead time }\end{array}$ & $\begin{array}{l}\text { Public transport used for certain } \\
\text { deliveries; courier services and } \\
\text { third-party transport used for } \\
\text { international orders }\end{array}$ & $\begin{array}{l}\text { Shared factory space; shared } \\
\text { storeroom }\end{array}$ & Internet café \\
\hline 2 & $\begin{array}{l}\text { Customer factory visits; deliver } \\
\text { to customers both locally and } \\
\text { internationally; exhibitions used }\end{array}$ & $\begin{array}{l}\text { Factory visit, by phone, by email } \\
\text { and at exhibitions; } \\
\text { big order }-2 \text { week lead time }\end{array}$ & $\begin{array}{l}\text { Own transport (delivery vehicle); } \\
\text { courier services and } \\
\text { third-party transport }\end{array}$ & $\begin{array}{l}\text { Rented space; small showroom and } \\
\text { production space }\end{array}$ & Internet café \\
\hline 3 & $\begin{array}{l}\text { Customer factory visits and sales at } \\
\text { exhibitions }\end{array}$ & $\begin{array}{l}\text { Factory visit, by phone, email, } \\
\text { and exhibitions; big order } \\
-2 \text { week lead time }\end{array}$ & $\begin{array}{l}\text { Public transport used for local } \\
\text { deliveries; courier services used } \\
\text { for international deliveries }\end{array}$ & $\begin{array}{l}\text { Own house used to produce goods - } \\
\text { one room for production, showroom } \\
\text { and storage }\end{array}$ & Internet café \\
\hline 4 & $\begin{array}{l}\text { Customers visit stall at the flea } \\
\text { market where good are sold } \\
\text { to them }\end{array}$ & $\begin{array}{l}\text { Orders placed at outlet visit, } \\
\text { by phone; big order - } 2 \text { week } \\
\text { lead time }\end{array}$ & $\begin{array}{l}\text { Flea market visit by customers } \\
\text { using their own transport (no } \\
\text { outbound transport needed) }\end{array}$ & $\begin{array}{l}\text { Flea market stall, rented storeroom; } \\
\text { own house for keeping extra stock }\end{array}$ & Internet café \\
\hline 5 & $\begin{array}{l}\text { Customer factory visits; delivery } \\
\text { to customers both locally and } \\
\text { internationally; exhibitions used to } \\
\text { sell products }\end{array}$ & $\begin{array}{l}\text { Factory visit, by phone, email } \\
\text { and at exhibitions; big order } \\
\text { - } 2 \text { week lead time }\end{array}$ & $\begin{array}{l}\text { Own transport used for local } \\
\text { delivery to customers; courier } \\
\text { services used for international } \\
\text { orders }\end{array}$ & $\begin{array}{l}\text { Rented space used for production; } \\
\text { small showroom and a very small } \\
\text { area used for production }\end{array}$ & $\begin{array}{l}\text { Own computer with } \\
\text { Internet and email } \\
\text { access }\end{array}$ \\
\hline 6 & $\begin{array}{l}\text { Customer factory visits; delivery } \\
\text { to customers both locally and } \\
\text { internationally; exhibitions used } \\
\text { to sell product }\end{array}$ & $\begin{array}{l}\text { Factory visit, by phone, email } \\
\text { and at exhibitions; big order } \\
-2 \text { week lead time }\end{array}$ & $\begin{array}{l}\text { Public transport used for local } \\
\text { deliveries; courier services used } \\
\text { for international deliveries }\end{array}$ & $\begin{array}{l}\text { Rented space; small showroom and } \\
\text { production space }\end{array}$ & Internet café \\
\hline 7 & $\begin{array}{l}\text { Customer factory visit; deliver to } \\
\text { customers; exhibition and/or fashion } \\
\text { shows used }\end{array}$ & $\begin{array}{l}\text { Factory visit, by phone, email } \\
\text { and at exhibitions; big order } \\
-2 \text { week lead time }\end{array}$ & $\begin{array}{l}\text { Own transport and } \\
\text { courier services }\end{array}$ & $\begin{array}{l}\text { Rented space; small showroom and } \\
\text { production space }\end{array}$ & $\begin{array}{l}\text { Own computer with } \\
\text { Internet and email } \\
\text { access }\end{array}$ \\
\hline 8 & $\begin{array}{l}\text { Customer factory visit; deliver } \\
\text { to customers both local and } \\
\text { international, as well at exhibitions }\end{array}$ & $\begin{array}{l}\text { Factory visit, by phone, email } \\
\text { and at exhibition; big order } \\
-2 \text { week lead time }\end{array}$ & $\begin{array}{l}\text { Public transport used for local } \\
\text { deliveries; courier services used } \\
\text { for international deliveries }\end{array}$ & $\begin{array}{l}\text { Rented space; small showroom and } \\
\text { production space }\end{array}$ & Internet café \\
\hline 9 & $\begin{array}{l}\text { Customer factory visits; deliver to } \\
\text { customers and at exhibitions and } \\
\text { fashion shows }\end{array}$ & $\begin{array}{l}\text { Outlet visits, phone, email and } \\
\text { exhibitions; big order - } \\
2 \text { week lead time }\end{array}$ & $\begin{array}{l}\text { Public transport for local } \\
\text { deliveries; courier services for } \\
\text { international deliveries }\end{array}$ & $\begin{array}{l}\text { Rented retail space for selling and } \\
\text { stock keeping; use own home for } \\
\text { production }\end{array}$ & Internet café \\
\hline
\end{tabular}


Customers can also buy products at the various exhibitions in which respondents are involved, from retail stores selling their products or from the stall in case of Respondents 4 and 9. Various order management systems are used by respondents: customers can either, (1) phone to place the order, (2) place orders via email, (3) physically place orders at the exhibition where items are displayed or (4) visit the factory where items are made. Whilst certain smaller orders are processed very quickly within minutes (especially at exhibitions and during factory-visit sales where finished goods are readily available), it often takes up to 2 weeks for the respondents to process a large order.

Craft businesses use either their own vehicles or thirdparty logistics operators to distribute their products locally and internationally. In terms of transport modes used and transport infrastructure (vehicles etc.), only Respondents 2, 5 and 7 have their own transport (one a delivery vehicle and one a sedan). Respondents $1,3,4$, $6,7,8$ and 9 use public transport to deliver products to customers locally and/or third-party courier companies to ship products internationally via air transport (unless the package delivered is abnormally large, then sea transport is occasionally used as it is more cost-efficient). International customers pay for the courier expenses.

Respondents often make use of third-party operators for very large local deliveries. This is expensive and craft producers often lack the experience and time to source a reasonably priced transport method locally, often ending up paying far more than what they should (as a result of their lack of logistics and transport knowledge regarding the competitiveness of rates charged). As transport is needed as and when a customer buys, it makes it difficult for them to develop relationships with the transport suppliers and thereby leverage better rates over the long term. The lack of development of alliances and healthy relationships with transporters was evident with most respondents.

All respondents utilise their own production facilities and storage facilities or warehousing to create and store their products In terms of physical production facilities and storage space (warehousing), all the respondents have their own rented factory space. They use the space for production, stock keeping and as a sales display area. Only two of the respondents, 5 and 7, have their own computers and Internet connections (via 3G), whilst the others access computers at Internet cafés.

\section{Conclusion}

What has emerged from the research conducted is that a significant gap (of supply chain alignment) exists between the creative and innovative products produced by craft businesses in Gauteng and a correspondingly creative and appropriate SCM strategy. A number of craft businesses simply 'grew beyond their boots' and struggled to match their successful product strategies with their 'not-so-successful' SCM strategies. This lack of supply chain alignment became even more acute as the craft businesses grew and required an even greater number of products to be distributed or sold through outbound channels of distribution (once successfully produced). Certain craft businesses interviewed even revealed inbound supply chain weaknesses where the volume of raw materials, and speedy access to their raw materials required for production, did not match the actual production targets. Simply put, they often lacked the appropriate levels of raw materials needed to make an everexpanding repertoire of popular products produced.

Some of the producers in the craft industry copy products from competitors. As a result, the majority of products are similar with little differentiation. Those producers who have unique designs have greater competitive advantages over those who do not. They are able to differentiate themselves from competitors and to attract those customers that look for something different in the market in order to satisfy their individual and unique needs.

In terms of supply chain and logistics efficiency of the small craft businesses interviewed, it was discovered that they had very poorly defined and coordinated logistics systems in general and could either not afford or utilise transport and storage optimally. The researchers also conclude that these businesses could easily have made significant savings by managing their inventory and by forecasting more effectively, by transporting products more cost-efficiently using longerterm agreements with either one or fewer suppliers, by optimising inbound supplies in terms of planning and quantities required, as well as by optimising the outbound movement of products to international customers.

\section{Acknowledgements Competing interests}

The authors declare that they have no financial or personal relationships that may have inappropriately influenced them in writing this article.

\section{Authors' contributions}

C.V. (University of Johannesburg) was the project leader and was responsible for putting the work together, guiding the study, writing literature and presenting some results, discussion and conclusion. K.M.M. (Vaal University of Technology) conceptualised the idea, collected data and also contributed to the literature review and results and discussion.

\section{References}

Alsem, K.J., 2007, Strategic marketing: An applied perspective, McGraw-Hill Irwin, New York.

Arbuthnot, J.J., Slama, M. \& Sisler, G., 1993, 'Selection criteria and information sources in the purchase decisions of apparel buyers of small retailing firms', Journal of Small Business Management 31(2), 12-23.

Arnold, R.T., Chapman, S.N. \& Clive, L.M., 2012, Introduction to materials management, Prentice-Hall, New York.

Benton, W.C., 2007, Purchasing and supply management, McGraw-Hill Irwin, New York.

Brander, J.A. \& Eaton, J., 1984, 'Product line rivalry', The American Economic Review 74(3), 326-334.

Brynard, P.A. \& Hanekom, S.X., 2006, Introduction to research in management related fields, Van Schaiks, Pretoria. 
Burt, D.A., Petcavage, S.D. \& Pinkerton, R.L., 2012, Proactive purchasing in the supply chain, McGraw-Hill, New York.

Cant, M.C., Strydom, J.W., Jooste, F.C.J. \& Du Plessis, P.J., 2006, Marketing management, 5th edn., Juta, Cape Town.

Cooper, M.C. \& Ellram, L.M., 1993, 'Characteristics of supply chain management and the implications for purchasing and logistics strategy', The International Journal of Logistics Management 4(2), 13-24. http://dx.doi. org/10.1108/09574099310804957

Cravens, D.W. \& Piercy, N.F., 2009, Strategic marketing, 9th edn., McGraw-Hill Irwin, New York.

Cravens, D.W., Piercy, N.F. \& Prentice, A., 2000, 'Developing market-driven product strategies', Journal of Product \& Brand Management 9(6), 369-388. http://dx.doi. strategies, Journal of Product \& Brand
org/10.1108/10610420010356975

Davies, G., 1994, 'The delisting of products by retail buyers', Journal of Marketing Management 10, 473-493. http://dx.doi.org/10.1080/0267257X.1994.9964295

De Villiers, G., Nieman, G. \& Niemann, W., 2012, Strategic logistics management, Van Schaiks, Pretoria.

Ghiani, G., Laporte, G. \& Musmanno, R., 2013, Introduction to logistics systems management, John Wiley \& Sons, West Sussex. http://dx.doi. org/10.1002/9781118492185

Gilmore, A., Carson, D. \& Grant, K., 2001, 'SME marketing in practice', Marketing Intelligence \& Planning 19(1), $6-11 . \quad$ http://dx.doi. org/10.1108/02634500110363583

Gould, R., 2012, Creating the strategy: Winning and keeping customers in B2B markets, Kogan, London.

Hilletofth, P., 2009, 'How to develop a differentiated supply chain strategy', Industrial Management and Data Systems 109(1), 16-33. http://dx.doi. org/10.1108/02635570910926573

Hogarth-Scott, S., Watson, K. \& Wilson, N., 1996, 'Do small businesses have to practice marketing to survive and grow?', Marketing Intelligence \& Planning 14(1), 6-18. http://dx.doi.org/10.1108/02634509610106197

Hong, P. \& Jeong, J., 2006, 'Supply chain management practices of SMEs: From a business growth perspective', Journal of Enterprise Information Management 19(3), 292-302. http://dx.doi.org/10.1108/17410390610658478

Hopp, W.J. \& Xu, X., 2005, 'Product line selection and pricing with modularity in design', Manufacturing \& Service Operations Management 7(3), 172-187. design', Manufacturing \& Service Operations
http://dx.doi.org/10.1287/msom.1050.0077

Hough, J., Thompson, A.A., Strickland, A.J. \& Gamble, J.E., 2008, Crafting and executing strategy: Text, readings and cases, South African edn., McGraw-Hill Education, London.

Hugo, W.M.J. \& Badenhorst-Weiss, J.A., 2013, Purchasing and supply chain management, Van Schaiks, Pretoria.

lannuzzi, A., 2012, Greener products: The making and marketing of sustainable brands, CRC, London.

Jiao, J. \& Zhang, Y., 2005, 'Product portfolio planning with custome engineering interaction', IEE Transactions 37(9), 801-814. http://dx.doi. engineering interaction', IEE Tran
org/10.1080/07408170590917011

Khan, O. \& Creazza, A., 2009, 'Managing the product design-supply chain interface: Towards a roadmap to the "design centric business", International Journal of Physical Distribution and Logistics Management 39(4), 301-319. http://dx.doi. org/10.1108/09600030910962258

Laforet, S. \& Tann, J., 2006, 'Innovative characteristics of small manufacturing firms', Journal of Small Business and Enterprise Development 13(3), 363-380. http://dx.doi.org/10.1108/14626000610680253

Lambert, D.M. \& Cooper, M.C., 2000, 'Issues in supply chain management', Industrial Marketing Management 29, 65-83. http://dx.doi.org/10.1016/S00198501(99)00113-3

Lummus, R.R. \& Vokurka, R.J., 1999, 'Defining supply chain management: A historical perspective and practical guidelines', Industrial Management \& Data System 99(1), 11-17. http://dx.doi.org/10.1108/02635579910243851

Lummus, R.R., Krumwiede, D.W. \& Vokurka, R.J., 2001, 'The relationship of logistics to supply chain management: Developing a common industry definition', Industrial Management \& Data Systems 101(8), 426-431. http://dx.doi. org/10.1108/02635570110406730

Mangan, J., Lalwani, C., Butcher, T. \& Javadpour, R., 2012, Global logistics and supply chain management, John Wiley \& Sons, West Sussex.
Mather, H., 1992, 'Design for logistics (DFL) - The next challenge for designers', Production \& Inventory Management Journal 33(1), 7-11.

McLaughlin, E.W. \& Rao, V.R., 1990, 'The strategic role of supermarket buyer intermediaries in new product selection: Implications for system wide efficiency', American Journal of Agricultural Economics 72(2), 358-370. http://dx.doi.org/10.2307/1242339

Merrilees, B., 2007, 'A theory of brand-led SME new venture development', Qualitative Market Research: An International Journal 10(4), 403-415. http://dx.doi.org/10.1108/13522750710819739

Morgan, L.O., Daniels, R.L. \& Kouvelis, P., 2001, 'Marketing/manufacturing trade-offs in product line management', IIE Transactions 33, 949-962. http://dx.doi.org/10.1080/07408170108936886

Mosey, S., 2005, 'Understanding new-to-market product development in SMEs', International Journal of Operations and Production Management 25(2), 114-130. http://dx.doi.org/10.1108/01443570510576994

Mosey, S., Clare, J.N. \& Woodcock, D.J., 2002, 'Innovation decision making in British manufacturing SMEs', Integrated Manufacturing Systems 13(3), 176-183. http://dx.doi.org/10.1108/09576060210416625

Murphy, P.R. \& Wood, D.F., 2011, Contemporary logistics, Pearson, Boston.

Murphy, P.R., Daley, J.M. \& Knemeyer, A.M., 1999, 'Comparing logistics management in small and large firms: An exploratory study', Transportation Journal 38(4), 18-25.

Naudè, J.M. \& O'Neill, C., 2009, 'The quest for survival in the automotive industry: A supply chain perspective', paper presented at the International Business Management Conference, University of KwaZulu-Natal, Westville campus, November.

O'Dwyer, M. \& Ledwith, A., 2009, 'Determinants of new product performance in small firms', International Journal of Entrepreneurial Behaviour \& Research 15(2), 124-136. http://dx.doi.org/10.1108/13552550910944548

Pellegrini, L. \& Zanderighi, L., 2001, 'New products: Manufacturers' versus retailers' decision criteria', The International Review of Retail, Distribution \& Consumer Research 1(2), 149-174. http://dx.doi.org/10.1080/09593969100000014

Perreault, W.D. \& McCarthy, E.J., 1996, Basic Marketing: A global managerial approach, 12th edn., Irwin, New York.

Petersen, K.J., Handfield, R.B. \& Ragartz, G.L., 2005, 'Supplier integration into new product development: Coordinating product, process and into new product, development: Coordinating product, process and supply chain design', Journal of Operations
http://dx.doi.org/10.1016/j.jom.2004.07.009

Pienaar, W.J. \& Vogt, J.J., 2012, Business logistics management: A supply chain perspectives, 4th edn., Oxford University Press, Cape Town.

Quayle, M., 2003, 'A study of supply chain management practice in http://dx.doi.org/10.1108/13598540310463387

Quayle, M., 2006, Purchasing and supply chain management: Strategies and realities, Idea Group, New York.

Rainey, D.L., 2005, Product innovation, Cambridge University Press, London. http:// dx.doi.org/10.1017/CBO9780511541230

Salavou, H. \& Avlonitis, G., 2008, 'Product innovativeness and performance: A focus on SMEs', Management Decision 46(7), 969-985. http://dx.doi. org/10.1108/00251740810890168

Shimp, T.A. \& Andrews, J.C., 2013, Advertising, promotions and other aspects of integrated marketing communications, South Africa edn., Cengage Learning, Andover.

Simpson, M. \& Taylor, N., 2002, 'The role and relevance of marketing in SMEs: Towards a new model', Journal of Small Business and Enterprise Development 9(4), 370382. http://dx.doi.org/10.1108/14626000210450559

Tan, K.C., 2001, 'A framework of supply chain management literature', European Journal of Purchasing and Supply Management 7, 39-48. http://dx.doi.org/10.1016/S0969-7012(00)00020-4

Tang, Y., Wang, P. \& Zhang, Y., 2007, 'Marketing and business performance of construction SMEs in China', Journal of Business \& Industrial Marketing 22(2), 118-125. http://dx.doi.org/10.1108/08858620710730230

Trott, P., 2012, Innovation management and new product development, PrenticeHall, New York.

Vaaland, T.I. \& Heide, M., 2007, 'Can the SME survive the supply chain challenges?', Supply Chain Management: An International Journal 1(1), 20-31. http://dx.doi.org/10.1108/13598540710724374 